\title{
ACTIVATION OF CYCLOPENTANE IN AQUEOUS MEDIUM AND AT ROOM TEMPERATURE USING TRIS-BIPYRIDINE RUTHENIUM COMPLEX AS A PHOTOSENSITIZER.
}

\author{
Njapba, N. J.* and W.L. Waltz ${ }^{+}$ \\ * Departtment of Chemistry, University of Buea. \\ +Department of Chemistry, University of Saskatchewan, Canada
}

\begin{abstract}
In this study, the use of a transition metal complex, tris (2,2-bipyridine) ruthenium (II) as a photosensitizer to convert cyclopentane into other compounds in an aqueous medium and at room temperature and pressure has been investigated. Peroxydisulphate ion has been used as a radical source. The irradiation of the solutions have been carried out at 436- $\mathrm{nm}$ wavelength using a high pressure mercury lamp for the light source. Cyclopentanol and cyclopentanone have been obtained as organic products. The products were detected and characterized using gas chromatography and mass spectrometry methods. They were formed at concentration levels of 10${ }^{4} \mathrm{M}$. The quantum yields of total product formation were about 0.2 at a light intensity of $5 \times 10^{16}$ quanta/s.
\end{abstract}

RÉSUMÉ: Dans cette étude, l'utilisation d'un complexe du métal de transition, le tris (bipyridine2,2) ruthénium (II), comme photosensibilisateur pour transformer le cyclopentane en d'autres composés dans un milieu aqueux et à température et pression ambiantes a été examiné. Nous avons utilisé l'ion peroxydisulfate comme souce radicale. L'irradiation des solutions s'est effectuée à 436 $n m$ de longueur d'onde avec utilisation d'une lampe de mercure à forte pression pour la source lumineuse. Nous avons obtenu du cyclopentanol et de la cyclopentanone comme produits organiques. Pour la détection et la caractérisation des produits, nous avons eu recours aux méthodes de chromatographie de gaz et de spectrométrie de masse. Les produits étaient formés à des niveaux de concentration de $10^{-4} \mathrm{M}$. Les rapports quantiques de la formation totale des produits étaient d'environ 0,2 pour une intensité lumineuse de $5 \times 10^{16}$ quanta/s. Dans cette étude, l'utilisation d'un complexe du métal de transition, le tris (bipyridine-2,2) ruthénium (II), comme photosensibilisateur pour transformer le cyclopentane en d'autres composés dans un milieu aqueux et à température et pression ambiantes a été examiné. Nous avons utilisé l'ion peroxydisulfate comme souce radicale. L'irradiation des solutions s'est effectuée à $436 \mathrm{~nm}$ de longueur d'onde avec utilisation d'une lampe de mercure à forte pression pour la source lumineuse. Nous avons obtenu du cyclopentanol et de la cyclopentanone comme produits organiques. Pour la détection et la caractérisation des produits, nous avons eu recours aux méthodes de chromatographie de gaz et de spectrométrie de masse. Les produits étaient formés à des niveaux de concentration de $10^{-4} \mathrm{M}$. Les rapports quantiques de la formation totale des produits étaient d'environ 0,2 pour une intensité lumineuse de $5 \times 10^{16}$ quanta/s.

\section{INTRODUCTION}

Saturated hydrocarbons are the major constituents of natural gas and petroleum. A major problem exists with the activation of saturated hydrocarbons due to the chemical inertness of the compounds. An understanding of the $\mathrm{C}-\mathrm{H}$ activation mechanism should help to develop methods for converting saturated hydrocarbons into more reactive compounds. Many of the studies have been carried out in organic media that are potentially toxic to the environment. Only a few studies have been carried out on the activation of alkanes in an aqueous medium due to the limited solubility of alkanes in water. Most of the studies have been carried out using pulse and continuous radiolysis in combination with absorption detection methods. ${ }^{1,2,3}$ In many of these studies, the products formed under slightly different conditions are often different. Schuler and Solylemez in a detailed study on the radiolysis of an aqueous solution of cyclopentane in the presence of $\mathrm{N}_{2} \mathrm{O}$ found mainly alcohols and ketones as products. ${ }^{2}$ But 
Sonntag and coworkers found aldehydes as major products in addition to the alcohols and ketones in the radiolysis of oxygenated aqueous solution of cyclopentane. ${ }^{1}$

In the present study, a new method involving the use of light in the visible region together with a transition metal complex as photosensitizer has been explored for the conversion of a low molecular weight saturated hydrocarbon into more reactive compounds. The study was carried out in the presence of peroxide in aqueous media at room temperature $\left(25^{\circ} \mathrm{C}\right)$ and pressure. Not only is low energy light being used but the availability of visible light from the sun makes this form of energy input one of the cheapest and most abundantly available sources. The medium in which the studies were carried out, water, is non-toxic to the environment.

Transition metal complexes containing bipyridine have been found to be suitable for solar energy conversion because of the photochemistry of their excited states, especially the ability to undergo electron transfer reactions. ${ }^{4,5}$ The transition metal complex tris $(2,2-$ bipyridine) ruthenium (II) has properties that make it most suitable among current transition metal complexes for this purpose. It absorbs strongly in the visible region having maximum wavelength at $452 \mathrm{~nm}$ with an absorption coefficient of $1.4 \times 10^{4} / \mathrm{M} / \mathrm{cm} .{ }^{6}$ It is stable towards photodissociation at room conditions. ${ }^{7}$ The lowest excited state is formed with unitary efficiency and a long enough lifetime $\left(6 \times 10^{-7} \mathrm{~s}\right)$ to be involved in bimolecular processes such as electron transfer. ${ }^{6}$

Peroxydisulphate ion reacts with the excited state of $\mathrm{Ru}$ (bpy) ${ }_{3}{ }^{2+}$ (oxidative quenching) to form the sulphate radical which has been shown to abstract hydrogen atoms from saturated hydrocarbons. ${ }^{6,8,9}$

Cyclopentane was chosen for this study because it is the most soluble among the liquid-saturated hydrocarbons in water $\left(2.5 \times 10^{-3} \mathrm{M}\right)$ and its radical chemistry is expected to be relatively simple since all the hydrogen atoms are equivalent. ${ }^{2,10}$

\section{EXPERIMENTAL}

Tris(2,2-bipyridine) ruthenium (II) perchlorate was prepared from the chloride salt, obtained from G.F. Smith chemical company. The maximum absorption coefficients obtained, $1_{\max } \mathrm{nm}(\mathrm{e} / \mathrm{M} / \mathrm{cm}), 452\left(1.4 \times 10^{4}\right), 285\left(8.4 \times 10^{4}\right), 250(3.7 \mathrm{x}$ $\left.10^{4}\right)$ agreed, to within $1 \%$, to those reported in the literature. ${ }^{6}$ Potassium ferrioxalate $\mathrm{K}_{3} \mathrm{Fe}\left(\mathrm{C}_{2} \mathrm{O}_{4}\right)_{3} \cdot 3 \mathrm{H}_{2} \mathrm{O}$, used for actinometry was prepared as stated in the literature. ${ }^{11}$ Potassium peroxydisulphate obtained from Fisher Scientific
Co. (99\%) was recrystallized from a minimum amount of water and dried under vacuum for 24 hours. The absorption coefficients obtained, $1_{\text {max }} \mathrm{nm}(\mathrm{e} / \mathrm{M} / \mathrm{cm}) 230$ (98.5), 215 (299.0) agreed, to within $1.5 \%$, to those reported in the literature. $^{12}$

Potassium sulphate and all other inorganic chemicals (BDH analaR) were used without further purification. Cyclopentane, used as starting material in the experiments, was obtained from BDH (Omnisolv. Grade) and contained less than $0.5 \%$ organic impurities. Organic compounds used as standards in the product analysis and solvents used in the extractions of the organic products were of analytical grade. These were used without further purification. The $\mathrm{pH}$ of the solutions was standardized against certified buffer solutions obtained from Fisher Scientific Co. High purity helium gas (99.995\%) from Linde Union Carbide was used in deaerating the solutions.

All solutions were prepared using water purified by a Millipore Super-Q system ${ }^{13}$. The resistivity of the water was between 16 and 17 megohm-cm. In addition to the resistivity value, the quality of the water was periodically checked by recording the emission spectrum on the Spex Flurolog 222 spectroflurometer.

The pyrex glassware used in the preparation of the solutions was baked in an annealing furnance brought up to $500{ }^{\circ} \mathrm{C}$ and then allowed to cool. This eliminated any trace of impurities still left in the glassware.

A 500-watt high-pressure mercury arc lamp was used as the light source. Tap water was circulated through a $10-\mathrm{cm}$ by $4-\mathrm{cm}$ glass cell to cut off most of the infrared radiation from the lamp. A combination of interference filter (bandwidth of 10-cm) and a Corning coloured glass filter (370-nm cut off) were used to isolate the 436-nm wavelength. The light intensity from the lamp was measured by ferrioxalate actinometry.

The solutions were prepared prior to use and handled under red light conditions to minimize photolysis effect. Typical sample solutions containing 40 micromolar $\mathrm{Ru}(\mathrm{bpy})_{3}{ }^{2+}, 20$ millimolar $\mathrm{S}_{2} \mathrm{O}_{8}{ }^{2-}$ and 2.5 millimolar cyclopentane were photolyzed in a $100-\mathrm{cm}^{3}$ air tight glass syringe (3.5-cm i.d.).

The separation of the inorganic compounds from the organic compounds was accomplished by liquid-solid extraction technique using $\mathrm{C}_{18}$ sep-pak cartridges obtained from Waters Associates. Sulphate and peroxydisulphate ions pass through the cartridge unretained while organic compounds and $\mathrm{Ru}(\mathrm{bpy})_{3}{ }^{2+}$ ions are retained. This procedure quickly separates the peroxydisulphate from the 
ruthenium complex and precludes further reaction between the two. Acetophenone was used as a solvent at $25^{\circ} \mathrm{C}$ to elute the organic compounds without removing the ruthenium complex from the cartridge. This allows for the analysis of the products on the gas chromatogram without interference from the inorganic compounds.

The organic products were separated by gas chromatography and detected with a flame ionization detector or mass spectrometer. Measurements were made on the Hewlett-Packard 5890A gas chromatograph coupled to an HP 3392A Intergrator. The J \& W Scientific DB5 (5\% phenyl) column, 30 meter by 0.53 micrometer i.d. and coated with 1.5 micrometer film was used but could not separate cyclopentanol and cyclopentanone. The separation could be achieved on a packed OV 210 (50\% trifluropropyl) 3.65 $\mathrm{m}$ by $3 \mathrm{~mm}$ o.d. stainless steel column. The stationary phase was $3 \%$ coated on the chromosorb acid washed and silanized support. The detection limit was $10^{-4} \mathrm{M}$ on this column compared to $10^{-5} \mathrm{M}$ on the DB5 column. Total-ion chromatogram were obtained by using the HP 5890A gas chromatograph coupled to a vacuum-Generator Analytical MS-12 mass spectrometer.

pH measurements were made using an Orion model 801A digital ion analyser in conjunction with a Fischer combination electrode. Changes in the concentration of the ruthenium complex were monitored spectrophotometrically on a carry 2315 spectrophotometer.

\section{RESULTS AND DISCUSSIONS}

Studies were conducted by monitoring the absorption spectra changes of $\mathrm{Ru}(\mathrm{bpy})_{3}{ }^{2+}$ and the $\mathrm{pH}$ changes of the solution, and by determining the organic products formed. The bleaching of $\mathrm{Ru}(\mathrm{bpy})_{3}{ }^{2+}$ ground state absorption maximum at 452-nm occurs with concomitant formation of an absorption peak at 420-nm (peak maximum of $\left.\mathrm{Ru}(\mathrm{bpy})_{3}{ }^{3+}\right)^{14}$. At a light-intensity of $4 \times 10^{18}$ quanta s $^{-1}$, the $\mathrm{Ru}$ (bpy) ${ }_{3}{ }^{2+}$ complex ion is converted to $\mathrm{Ru}(\mathrm{bpy})_{3}{ }^{3+}$ in less than a minute and the peak maximum at $452-\mathrm{nm}$ is observed to increase with increased irradiation (Figure 1).

This observation is likely due to photochemical (perhaps some thermal) reduction of $\mathrm{Ru}(\mathrm{bpy}){ }_{3}{ }^{3+}$ to $\mathrm{Ru}(\mathrm{bpy})_{3}{ }^{2+}$. At a lower light-intensity $\left(2 \times 10^{17}\right.$ quanta $\left.^{-1}\right)$, the absorption spectrum of the solution at 5-minute photolysis shows the complete conversion of the $\mathrm{Ru}(\mathrm{bpy})_{3}{ }^{2+}$ to $\mathrm{Ru}(\mathrm{bpy})_{3}{ }^{3+}$. Prolonged photolysis leads to an increase in the $452 \mathrm{~nm}$ peak which decreases after 60 minutes of irradiation (Figure 2).

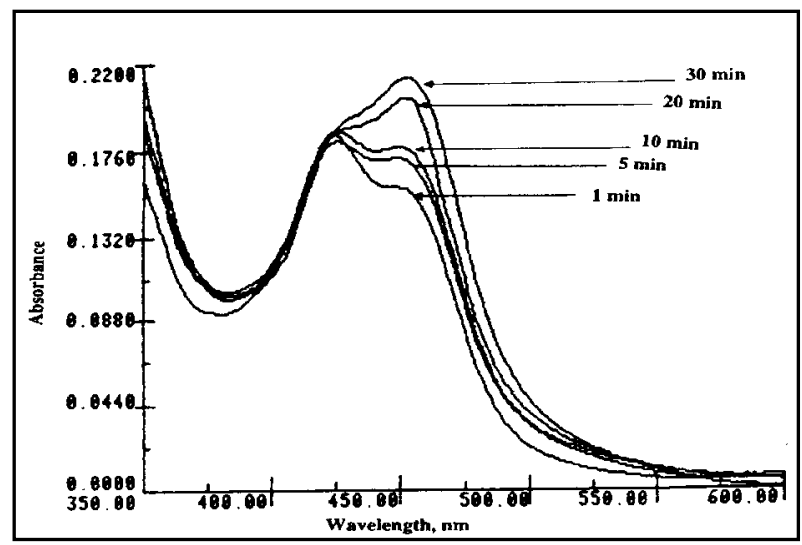

Figure 1. Absorption spectral changes of solutions immediately after photolysis at a light intensity of $4 \times 10^{18}$ quanta s${ }^{-1}$ and natural $\mathrm{pH}$ (ca. 5.2). Solutions irradiated in $3.5-\mathrm{cm}$ cell but absorption measurements conducted in a $1-\mathrm{cm}$ cell. The numbers shown on each spectrum indicate time of photolysis.

Conditions: $40 \mathrm{mM} \mathrm{Ru(bpy)}{ }_{3}{ }^{2+}, 20 \mathrm{mM} \mathrm{S}_{2} \mathrm{O}_{8}{ }^{2-}, 0.1 \mathrm{M} \mathrm{SO}_{4}{ }^{2-}$ and saturated with cyclopentane; room temperature $\left(25 \pm 3^{\circ} \mathrm{C}\right)$.

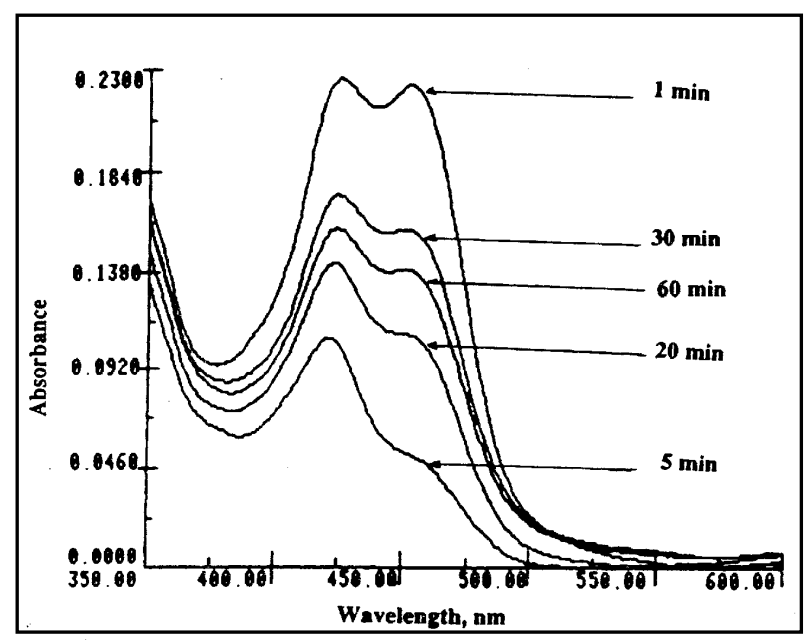

Figure 2. Absorption spectral changes of solutions immediately after photolysis at a light intensity of $2 \times 10^{17}$ quanta $^{-1}$ and natural $\mathrm{pH}$ (ca.5.2).

As can be seen in Figures 1 and 2, both the 420-nm and 452-nm peaks are present in solution at all times indicating that photo-oxidation of $\mathrm{Ru}(\mathrm{pby})_{3}{ }^{2+}$ and photo-reduction of $\mathrm{Ru}(\mathrm{bpy})_{3}{ }^{3+}$ are likely taking place simultaneously.

After photolysis, a continuous increase in absorption at the 452-nm peak was observed which is likely due to thermal reduction of $\mathrm{Ru}(\mathrm{bpy})_{3}{ }^{3+}$. The recovery occurs within a one to two-hour period and in all cases to less than $100 \%$ of the original concentration of $\mathrm{Ru}(\mathrm{bpy})_{3}{ }^{2+}$. The percentage of maximum recovery decreases with increasing irradiation time and light intensity (Table 1). 
Activation of Cyclopentane in aqueous Medium and at Room Temperature Using Tri-bipyridine Ruthenium Complex as a Photosensitizer

Table 1. Percentage Thermal Recovery (PTR) of $\mathrm{Ru}(\mathrm{bpy})_{3}{ }^{2+}$ in the dark after photolysis. ${ }^{\mathrm{a}}$

\begin{tabular}{|c|c|c|}
\hline \multirow{2}{*}{$\begin{array}{c}\text { Irradiation Time } \\
\text { (minutes) }\end{array}$} & \multicolumn{2}{|c|}{ PTR } \\
\cline { 2 - 3 } & $4 \times 10^{18}$ quanta s$^{-1}$ & $5 \times 10^{16}$ quanta s$^{-1}$ \\
\hline 1.0 & 68 & 80 \\
5.0 & 75 & 73 \\
10.0 & 72 & 72 \\
20.0 & 58 & 66 \\
30.0 & 47 & 53 \\
60.0 & 42 & 54 \\
\hline
\end{tabular}

a Solutions consisted of $40 \mathrm{mM} \mathrm{Ru}(\mathrm{bpy})_{3}{ }^{2+}, 20 \mathrm{mM} \mathrm{S}_{2} \mathrm{O}_{8}{ }^{2-}, 0.1 \mathrm{M}$ $\mathrm{SO}_{4}{ }^{2-}$ and saturated with cyclopentane. $40 \mathrm{~mL}$ of solutions irradiated at natural $\mathrm{pH}$ (ca. 5.2) and room temperature $\left(25 \pm 3^{\circ} \mathrm{C}\right)$ in a $3.5-\mathrm{cm}$ cell. Absorption measurements made in a $1-\mathrm{cm}$ cell. Calculations are based on absorbance at $452-\mathrm{nm}$ peak using the value before photolysis as a base.

This suggests a degradation of the ruthenium complex during photolysis. Studies have shown that reduction of $\mathrm{Ru}(\mathrm{bpy})_{3}{ }^{3+}$ to $\mathrm{Ru}(\mathrm{bpy})_{3}{ }^{2+}$ occurs with about $10 \%$ degradation of the trisbipyridine complex in aqueous solution at room temperature and over a $\mathrm{pH}$ range $0-12 .{ }^{15}$ Both the thermal and the photo-induced reduction proceed to the same products which have been identified by the use of high-performance liquid chromatography to be modified $\mathrm{Ru}(\mathrm{II})$ complexes. $^{15}$ It is thus likely that the incomplete recovery of $\mathrm{Ru}(\mathrm{bpy})_{3}{ }^{2+}$ is due to repetitive cycles of $\mathrm{Ru}(\mathrm{bpy})_{3}{ }^{3+}$ reduction and oxidation reactions. The exact nature of the decomposed products in this study was not determined.

The $\mathrm{pH}$ of the photolyzed solution was observed to decrease with time of irradiation and light intensity. But the decrease in $\mathrm{pH}$, which is attributed to the generation of hydrogen ions in solution, is relatively small. Correspondingly, the approximate quantum yield of hydrogen ions formed are low. (Table 2).

Table 2. Charge of pH of sample solutions with time of Irradiation. ${ }^{\mathrm{a}}$

\begin{tabular}{|c|c|c|c|c|}
\hline \multirow{2}{*}{$\begin{array}{c}\text { Time } \\
\text { (minutes) }\end{array}$} & \multicolumn{2}{|c|}{$4 \times 10^{18}$ quant a s $^{-1}$} & \multicolumn{2}{c|}{$5 \times 10^{16}$ quanta s $^{-1}$} \\
\cline { 2 - 5 } & $\mathrm{pH}$ & ${ }^{\mathrm{f}} \mathrm{H}^{+(\mathrm{b})}$ & $\mathrm{pH}$ & ${ }^{\mathrm{f}} \mathrm{H}^{+(\mathrm{b})}$ \\
\hline 1.0 & 4.91 & 0.03 & 5.39 & 0.8 \\
5.0 & 4.18 & 0.03 & 4.96 & 0.4 \\
10.0 & 4.10 & 0.02 & 4.84 & 0.3 \\
20.0 & 3.85 & 0.02 & 4.67 & 0.2 \\
30.0 & 3.65 & 0.02 & 4.05 & 0.6 \\
60.0 & 3.09 & 0.03 & 3.90 & 0.4 \\
\hline
\end{tabular}

a Solutions thermostated at $25 \pm 0.3{ }^{\circ} \mathrm{C}$ and $\mathrm{pH}$ meter standardized with buffer solutions of $\mathrm{pH} 7.00$ and $4.00 \mathrm{pH}$ values are accurate to $\pm 0.02 \mathrm{pH}$ units.

b Quantum yield of hydrogen ions formed in solution.
The only detectable organic products were cyclopentanol and cyclopentanone. Their concentration was determined by GC-FID using calibration curves of standard solutions. As the time of photolysis increases, the amount of total products formed increases. However the quantum yield for the total product decreases as does the ratio of alcohol to ketone. No products could be detected at a photolysis time less than ten minutes (Table 3 ).

Table 3. Organic products formed at a light intensity of $4 \mathrm{x}$ $10^{18}$ quanta $\mathrm{s}^{-1}$ and natural $\mathrm{pH}^{\mathrm{a}}$

\begin{tabular}{|c|c|c|c|c|}
\hline $\begin{array}{c}\text { Time } \\
\text { (minutes) }\end{array}$ & $\begin{array}{c}{\left[\mathrm{C}_{5} \mathrm{H}_{9} \mathrm{OH}\right] \times \mathrm{x}} \\
10^{4} \mathrm{M}\end{array}$ & $\begin{array}{c}{\left[\mathrm{C}_{5} \mathrm{H}_{8} \mathrm{O}\right] \times} \\
10^{4} \mathrm{M}\end{array}$ & {$\left[\mathrm{C}_{5} \mathrm{H}_{9} \mathrm{OH}\right]$} & \multirow{2}{*}{\begin{tabular}{c} 
Total product \\
\cline { 3 - 4 }
\end{tabular}} \\
\cline { 4 - 5 } & 2.1 & 1.0 & 2.1 & \\
\hline 10 & 4.1 & 2.3 & 1.8 & 0.08 \\
30 & 5.8 & 4.3 & 1.3 & 0.05 \\
60 & & &
\end{tabular}

a Each value in the table represents an average of three determinations and is reproducible to $\pm 0.2 \times 10^{-4} \mathrm{M}$. Values are obtained by GC analysis using an OV 210 packed column ( 3.65 by 3 $\mathrm{mm}$ o.d). Sample size injected $1 \mathrm{~mL}$. Solutions consisted of $40 \mathrm{~mL}$ deaerated $40 \mathrm{mM} \mathrm{Ru}\left(\right.$ bpy) ${ }_{3}{ }^{2+}, 20 \mathrm{mM} \mathrm{S}_{2} \mathrm{O}_{8}{ }^{2-}, 0.1 \mathrm{M} \mathrm{SO}_{4}{ }^{2-}$ and saturated with cyclopentane, passed through a $\mathrm{C}_{18}$ sep-pak cartridge and organic products extracted with $2 \mathrm{~mL}$ of acetophenone.

b Calculations based on the assumption that $100 \%$ light is absorbed.

The formation of the organic products is clearly photodependent. No organic products were formed when solutions were stored in the dark for as long as 24 hours. The greater the light input, the greater the amount of products formed (Tables 3 and 4). More importantly, solutions photolysed and analysed immediately after photolysis and those allowed to stand for further one to two hours before analysis were found to contain the some amounts of products. This implies that formation of products stops once the light is turned off.

Table 4. Organic products formed at a light intensity of $5 \mathrm{x}$ $10^{16}$ quanta $\mathrm{s}^{-1}$ and natural $\mathrm{pH}$.

\begin{tabular}{|c|c|c|}
\hline Time (minutes) & Total Products x $10^{4} \mathrm{M}^{\mathrm{a}}$ & $\phi_{\text {product }}{ }^{\mathrm{b}}$ \\
\hline 30 & 0.3 & 0.2 \\
60 & 0.5 & 0.18 \\
120 & 1.0 & 0.17 \\
\hline
\end{tabular}

a Each value in the table represents an average of three determinations. The values are reproducible to $\pm 0.2 \times 10^{-4} \mathrm{M}$. Measurements made on a DB5 Megabore column (30 m by 0.53 mm i.d.) operated at a constant temperature of $35{ }^{\circ} \mathrm{C}$. Samples sizes $1 \mathrm{~mL}$.

b Calculations based on the assumptions of total light absorption.

The excitation of $\mathrm{Ru}(\mathrm{bpy})_{3}{ }^{2+}$ in a deaerated aqueous solution with $436 \mathrm{~nm}$ light leads to the formation of a charge transfer triplet excited state, which in the presence of 
peroxydisulphate is quenched at a rate of $5.33 \times 10^{8} \mathrm{M}^{-1} \mathrm{~s}$ ${ }^{1}$ forming $\mathrm{Ru}(\mathrm{bpy})_{3}{ }^{3+}$ and $\mathrm{SO}_{4}{ }^{2-6,16}$.

The overall equation of the reaction can be written as follows:

$$
2 \mathrm{Ru}(\text { byp })_{3}^{2+*}+\mathrm{S}_{2} \mathrm{O}_{8}^{2-} \rightarrow 2 \mathrm{Ru}(\text { byp })_{3}^{3+}+2 \mathrm{SO}_{4}^{2-} \quad 1
$$

Because the overall quantum efficiency (i.e. Ru(bpy) ${ }_{3}^{3+}$ produced/photon absorb) as shown in equation 1 above is 2 , the following photo-induced oxidation scheme has been proposed. ${ }^{16,17}$

$$
\begin{aligned}
& \mathrm{Ru}(\mathrm{bpy})_{3}^{2+}+\mathrm{hv} \rightarrow \mathrm{Ru}(\mathrm{bpy})_{3}^{2+*} \\
& \mathrm{Ru}(\mathrm{bpy})_{3}^{2+*}+\mathrm{S}_{2} \mathrm{O}_{8}^{2-} \rightarrow \mathrm{SO}_{4}^{-}+\mathrm{SO}_{4}^{2-}+\mathrm{Ru}(\mathrm{bpy})_{3}^{3+} \\
& \mathrm{Ru}(\mathrm{bpy})_{3}^{2+}+\mathrm{SO}_{4}^{-} \rightarrow \mathrm{SO}_{4}^{2-}+\mathrm{Ru}(\mathrm{bpy})_{3}^{3+}
\end{aligned}
$$

The strongly oxidising intermediate $\mathrm{SO}_{4}^{-}$produced in equation 3 abstracts hydrogen atoms from alkanes to form alkyl radicals at rate constants greater than $10^{6} \mathrm{M}^{-1} \mathrm{~s}^{-1} .{ }^{9}$

In the presence of cyclopentane, the anion radical could react with cyclopentane to produce cyclopentyl radicals.

$$
\mathrm{SO}_{4}^{-}+\mathrm{C}_{5} \mathrm{H}_{10} \rightarrow \mathrm{C}_{5} \mathrm{H}_{9}^{-}+\mathrm{SO}_{4}^{-}+\mathrm{H}^{+}
$$

The cyclopentyl radical could then react with $\mathrm{S}_{2} \mathrm{O}_{8}{ }^{2-}$, which is present in large amounts in the solution, forming cyclopentyl cation.

$$
\mathrm{C}_{5} \mathrm{H}_{9}^{+}+\mathrm{S}_{2} \mathrm{O}_{8} \rightarrow \mathrm{C}_{5} \mathrm{H}_{9}^{+}+\mathrm{SO}_{4}^{-}+\mathrm{SO}_{4}^{2-}
$$

The cyclopently cation then reacts with water to form cyclopentanol.

$$
\mathrm{C}_{5} \mathrm{H}_{9}^{+}+\mathrm{H}_{2} \mathrm{O} \rightarrow \mathrm{C}_{5} \mathrm{H}_{9} \mathrm{OH}+\mathrm{H}^{+}
$$

The cyclopentanol then further reacts with peroxydisulphate ion to produce cyclopentanone.

$$
\mathrm{C}_{5} \mathrm{H}_{9} \mathrm{OH}+\mathrm{S}_{2} \mathrm{O}_{8}^{2-} \rightarrow \mathrm{C}_{5} \mathrm{H}_{8} \mathrm{O}+2 \mathrm{H}^{+}+2 \mathrm{SO}_{4}^{2}
$$

The ratio of cyclopentanol to cyclopentanone for solutions photolysed at $4 \times 10^{18}$ quanta $\mathrm{s}^{-1}$ increases with longer periods of irradiation (Table 3). This is an indication of the alcohol being oxidised further to the ketone although it does not necessarily prove that the products were formed sequentially and not concurrently. Unfortunately the products for solutions photolysed at a lower light intensity and a shorter time of irradiation could not be analysed on the OV 210 column due to its lower detection limit $\left(10^{-4} \mathrm{M}\right)$. The products formed were at $10^{-5} \mathrm{M}$ (Table 4).

From the scheme above, every mole of cyclopentanol formed should lead to the formation of 2 moles of $\mathrm{H}^{+}$ions and every mole of cyclopentanone to 4 moles of $\mathrm{H}^{+}$ions. Whereas the ratio of hydrogen ions to total products formed is slightly greater than 2 at light intensity of $5 \times 10^{16}$ quanta $\mathrm{s}^{-1}$, it is less than 1 at $4 \times 10^{18}$ quanta $\mathrm{s}^{-1}$. The process of product formation is definitely more complicated than is suggested by the above equations. The amount of cyclopentane that disappeared from solution was generally greater than the total amount of products detected. Watersolution products may have been lost during the separation of organic compounds from inorganic ones on the $\mathrm{C}_{18}$ seppak cartridge. High performance liquid chromatography may provide answers to whether additional products are formed or not.

\section{CONCLUSION}

At natural $\mathrm{pH}$, the continuous photolysis of an aqueous solution consisting of $4 \times 10^{-5} \mathrm{M} \mathrm{Ru}(\mathrm{bpy})_{3}{ }^{2+}, 2 \times 10^{-2} \mathrm{M}$ $\mathrm{S}_{2} \mathrm{O}_{8}{ }^{2-}$, and saturated with cyclopentane leads to the formation of cyclopentanol and cyclopentanone as the only detectable organic products.

The decomposition of the tris-bipyridine ruthenium complex presents a major problem in the use of the metal complex as a photocatalyst since not all of it is regenerated during or after photolysis. This leads to wastage in the light input and calculated quantum yields of products are likely to be underestimated. This makes it difficult to know whether there is a chain reaction or not. More studies could be conducted to determine the nature of the degraded products and if possible find a way to prevent the decomposition of the metal complex during photolysis.

\section{REFERENCES}

1. C. Sonntag, M.N. Schuchamnn and H. Zzgota, J. Phys. Chem., 1984, 885589

2. R. H. Schuler and T. Soylemez, J. Phys. Chem., 1974, 781052

3. J. Rabani, M. Pick and M. Simic, J. Phys. Chem., 1974, 781049.

4. N. Sutin and C. Creutz, Pure and Appl. Chem., 1980, 522717.

5. V. Balzani, F. Bolletta, M. T. Gandolfi and M. Maesta, Topics Curr. Chem., 1978, 754.

6. K. Kalyanasundaran, Coord. Chem. Rev., 1982, 46 159 
7. J. V. Houten and R. J. Watts. J. Am. Chem. Soc., 1976, 984853.

8. A.R. Galloppo, J.O. Edwards, F. Difuria, G. Dlano and R. Curci, J. Org. Chem., 1974, 393020.

9. Y. Ogata, K. Tomizawa and K. Furuta, The Chemistry of Peroxides, S. Patai, ED., John Wiley \& Sons, New York, 1983, Chapter 21.

10. C. A. McAuliffe, J. Phys. Chem., 1966, 701267.

11. J. G. Calvert and J. N. Pitts, Jr., Photochemistry, John Wiley and Sons, New York, 1967.

12. G. Levey and E. J. Hart, J. Phys. Chem. 1975791642.

13. Super-Q Water System, Installation, Operational Maintenance Manuel; Millipore Crop. Bedford, MA, 1972.

14. H. S. White and A. J. Bard, J. Am. Chem. Soc., 1982, 1046893.

15. N. Sutin, C. Greutz, M. Chou, B.S. Brunschwig and P.K. Ghosh, J. Am. Chem. Soc., 1984, 1064772.

16. F. Bolletta, A. Junis, M. Maesri and D. Sandrini, Inorg. Chem. Acta., 1980, 44 L175.

17. A. Bard, H. S. White and W. G. Becker, J. Phys. Chem. 1984881849. 